\title{
The Influence of Isothermal Holding Times on Microstructural Evolution of X90 Linepipe Steel
}

\author{
Qi Zhou ${ }^{a}$, Xian-ming Zhao ${ }^{b * *}$, Zhuang $L i^{c}$, Xi-jun Cui ${ }^{d}$ \\ ${ }^{a}$ School of Environmental and Chemical Engineering, Shenyang Ligong University, Shenyang 110159, \\ China \\ ${ }^{b}$ The State Key Laboratory of Rolling and Automation, Northeastern University, Shenyang 110004, China \\ ${ }^{c}$ College of Materials Science and Engineering, Shenyang Aerospace University, Shenyang 110136, Liaoning, China \\ ${ }^{d}$ School of Mechanical, Materials, Mechatronic and Biomedical Engineering, University of Wollongong, \\ Wollongong, NSW, 2522, Australia
}

Received: September 04, 2018; Revised: December 18, 2018; Accepted: February 19, 2019

\begin{abstract}
Microstructural phase of linepipe steels depends on different isothermal conditions. Thermal cycling testing of X90 linepipe steel was conducted using a thermomechanical simulator. The results have shown that with increased holding time, the microstructure constituents change from the martensite and bainitic ferrites to granular bainite and polygonal ferrite. There was the amount of martensite in the microstructure for isothermal holding times of 5 and $10 \mathrm{~s}$ at $700^{\circ} \mathrm{C}$. The effects of the martensite strengthening were weak. The changes of the hardness curve are decided by microstructural phase and the precipitation behavior. The interphase precipitation seems to begin for isothermal holding times greater than $30 \mathrm{~s}$. It has a peak value for isothermal holding time of $600 \mathrm{~s}$. Some fcc $(\mathrm{Ti}, \mathrm{Nb})(\mathrm{N}, \mathrm{C})$ particles which belong to the MX-type precipitates were obtained at this condition. It is a major microstructural contributor to the hardness. The beneficial effects of the precipitates decreased considerably due to coarsening of the precipitates with prolonged holding, which results in the hardness quickly dropping. As a result, the hardness exhibited a low value after isothermal holding for $3600 \mathrm{~s}$ because the extent of precipitation strengthening was lessened and a lot of polygonal ferrites were formed.
\end{abstract}

Keywords: Linepipe steel, Isothermal transformation, Hardness, Precipitation.

\section{Introduction}

High strength low-alloy (HSLA) steels are widely used for pipelines, buildings, bridges, and ships because of their potential to obtain high strength-toughness combination ${ }^{1-4}$. Alloying elements such as $\mathrm{Mn}, \mathrm{Ni}, \mathrm{Cr}$, and $\mathrm{Mo}$ are added to achieve the hardenability of austenite in these HSLA steels. In addition to those alloying elements, microalloying elements such as $\mathrm{Nb}, \mathrm{Ti}$, and $\mathrm{V}$, precipitate in austenite $(\gamma)$ as carbides, nitrides, or carbonitrides during hot rolling, and contribute to the mechanical properties of the microalloyed steels via grain refinement, solid solution hardening, and precipitation hardening ${ }^{5}{ }^{9}$. When HSLA steels containing $\mathrm{Nb}$, Ti or V are transformed from austenite $(\gamma)$ into ferrite $(\alpha)$, alloy carbides are precipitated in parallel rows as a result of periodic nucleation at the migrating $\alpha / \gamma$ interface, which is called interphase precipitation ${ }^{10}$. Interphase precipitation is a major microstructural contributor to the hardness (strength) ${ }^{11}$.

HSLA steels are usually produced by thermomechanical control process (TMCP). TMCP consisting of controlled hot rolling followed by controlled cooling is used to maximise the benefits of the microalloy additions present in microalloyed steels ${ }^{12-14}$. Traditional TMCP of microalloyed steels is employed to refine grain size and produce multi-phase microstructures, which provides good combinations of high strength and low temperature impact toughness. Suitable processing parameters in conjunction with micoalloying help improve strength

*e-mail: zhaoxm@ral.neu.edu.cn through various mechanisms: microstructural refinement, solid solution hardening, precipitation strengthening, and dislocation hardening due to the modification of the resulting microstructure ${ }^{15}$. From a commercial perspective, the formation of precipitation is of interest for applications in the steel production process. There are few studies on interphase precipitation in X90 linepipe steel using controlled thermal cycling, even though it has been conducted under different isothermal holding times ${ }^{16}$. However, it is note worthy that the precipitation behavior develops during short isothermal holding times because it may be more important parameters in production lines. The present work will be able to clarify the variation in the hardness after the thermal cycle. Vickers hardness will first increase up to the maximum value, and then, decrease with the increase holding time. This phenomenon is attributed to the microstructural evolution and effective precipitation strengthening. The reasons which have yet to be investigated systematically would be made clear reasonably.

In this work, the TMCP simulations were conducted by using a laboratory thermomechanical simulator in X90 linepipe steel. The microstructures and the precipitation behavior of the specimens during different isothermal holding time were discussed by analyzing the phases and microconstituents and measuring the hardness value. The purpose is to a better understanding of the microstructure evolution characteristics under different isothermal conditions. 


\section{Experimental}

X90 linepipe steel was used in this study. The chemical composition of the experimental steel (mass percent, \%) is C $0.059,0.0045 \mathrm{~N}$, Si 0.230 , Mn 1.870, Al 0.025, S 0.0014, P 0.019, Ti+Nb+V 0.095, Ni 0.350, Cr 0.240, Cu 0.190, Mo 0.185 . Cylindrical specimens taken from hot-rolled material and machined $\varphi 8 \times 15 \mathrm{~mm}$ were used in this investigation. Thermal cycling experiments were performed in a Gleeble 1500 thermomechanical simulator. In order to construct continuous cooling transformation ${ }^{\circ} \mathrm{CCT}$ ) curves, double-pass compression test is shown in Fig. 1. In Fig. 1, specimens were electrically heated at rate of $10^{\circ} \mathrm{C} \mathrm{s}^{-1}$ to $1250^{\circ} \mathrm{C}$, held at this temperature for $180 \mathrm{~s}$ and cooled down to different deformation temperatures of 1100 and $950^{\circ} \mathrm{C}$, at $5^{\circ} \mathrm{C} \mathrm{s}^{-1}$, respectively. The double-pass compression test were employed with compressive strain values of $30 \%$ and $40 \%$ respectively at strain rate of $1^{\circ} \mathrm{C} \mathrm{s}^{-1}$, and interpass time was set $20 \mathrm{~s}$. Specimens were cooled in air to room temperature at rates of 0.3 to $3317^{\circ} \mathrm{C} \mathrm{s}^{-1}$ after deformation. The constituent of the microstructure at different cooling rates are presented in Fig. 2.

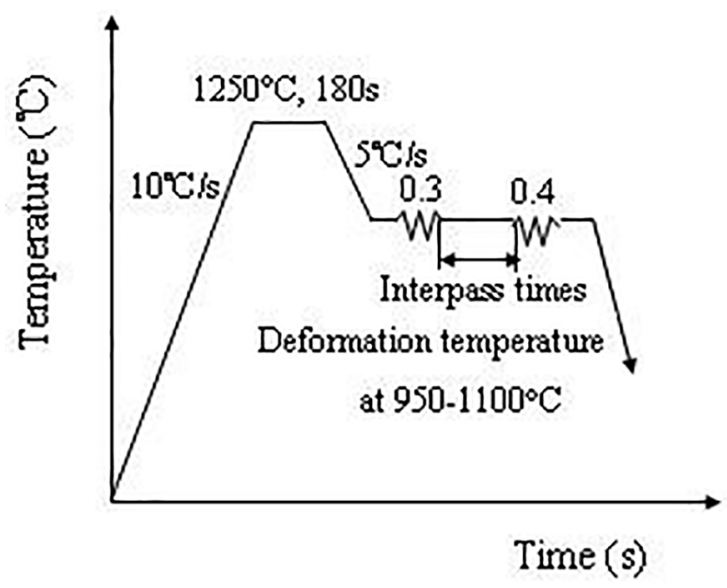

Figure 1. Schematic illustration of the double-pass compression test

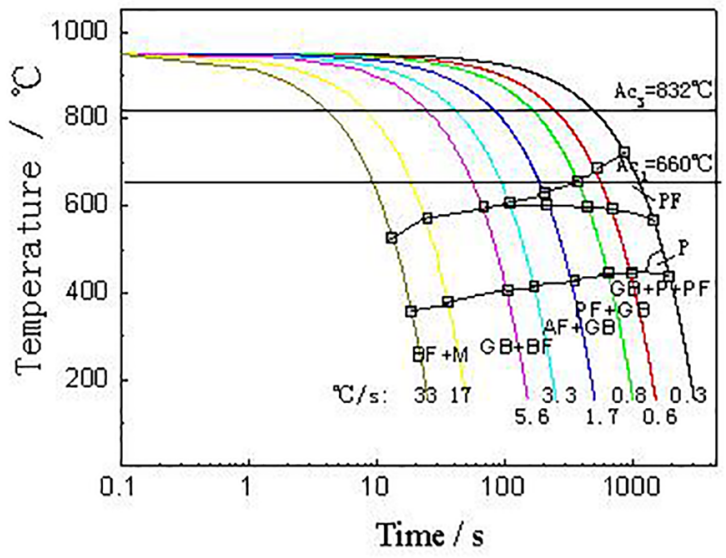

Figure 2. Experimental CCT for the steel (A: bainitic ferrite+martensite; $\mathrm{B}$ : granular bainite+bainitic ferrite; $\mathrm{C}$ : acicular ferrite+granular bainite; D: polygonal ferrite+granular bainite; E: granular bainite+ pearlite+polygonal ferrite; F: pearlite; G: polygonal ferrite)
The thermal processing schedule is shown in Fig. 3 The thermal cycling specimens were first heated to austenitic solution temperature $\left(1250^{\circ} \mathrm{C}\right)$ for $600 \mathrm{~s}$ to dissolve the precipitates present in the initial microstructure, compressed by twice to produce grain-refined microstructure, and followed by cooling to $700^{\circ} \mathrm{C}$ and isothermal holding for 5 , $10,30,60,600$, and $3600 \mathrm{~s}$. They were quenched to ambient temperature for terminating further precipitation. Finally, the specimens were tempered at $550^{\circ} \mathrm{C}$ for $1 \mathrm{~h}$ to detect the effect of interphase precipitation on hardness.

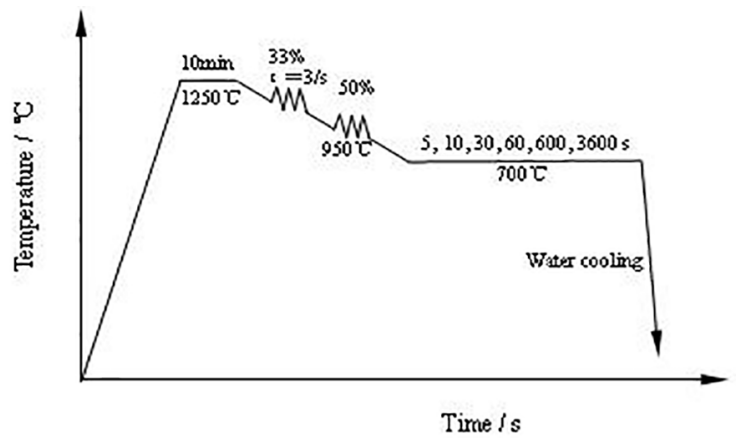

Figure 3. Schematic illustration of the thermomechanical processing simulation

Measurements of the Vickers hardness were performed under a load of $500 \mathrm{~g}$. Five hardness points were collected on each thermal cycling specimen. The specimens after thermal cycling for light optical microscopy (LOM) were polished and etched with $4 \%$ nital. These specimens for LOM were also colour etched using the LePera method ${ }^{17}$. Volume fractions and the microstructure constituents of the specimens were evaluated by Leica analyzer. This microscope with image analysis makes the measurement of the microstructure constituents perform in LOM image. The microstructure was investigated further by scanning electron microscopy (SEM) and transmission electron microscopy (TEM). The volume fractions of precipitates were assessed with the IPP image analysis software.

\section{Results and Discussion}

\subsection{Optical microscopy}

Optical micrographs of the experimental specimens are shown by the $500 \times$ magnification in Fig. 4. Martensite arose when the specimen was isothermally held for 5 and $10 \mathrm{~s}$ at $700^{\circ} \mathrm{C}$ (Fig. 4 (a, b). In Figs. 4 (a-d), bainitic ferrite which is the main microstructure constituent in the specimens was observed. Granular bainite formed with prolonged holding (Figs. 4 (b-f). The acicular ferrite formed with prolonged holding from 30 to $600 \mathrm{~s}$ (Figs. 4 (c-e). Polygonal ferrite was the predominant structure in the specimens for isothermal holding times of 60,600 , and 3600 s (Figs. 4 (d-f)). Pearlite could be observed when the specimen was isothermally held for $3600 \mathrm{~s}$ (Fig. 2 (f)). 

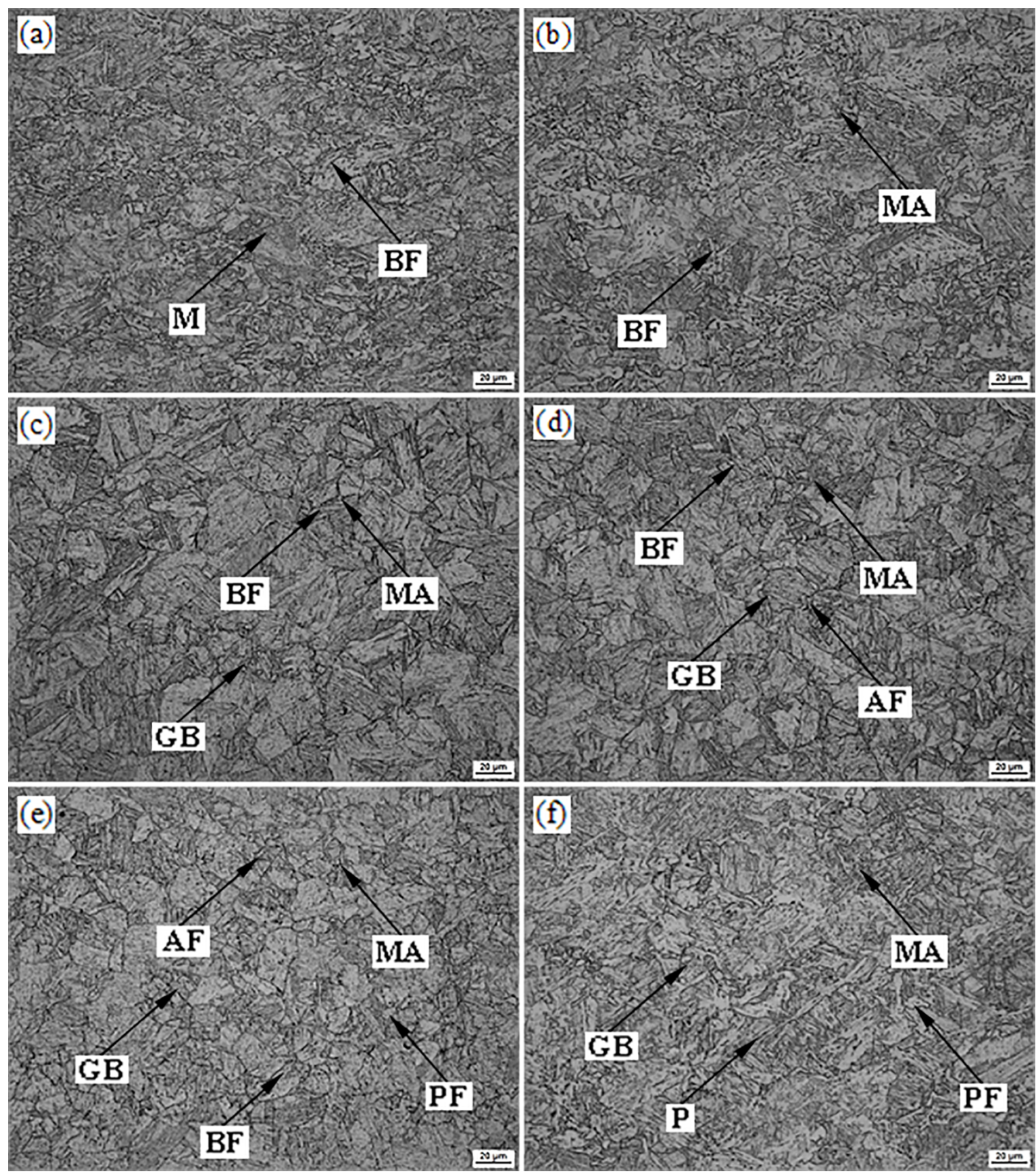

Figure 4. Optical micrographs of the specimens etched in 4\% nital held for (a) $5 \mathrm{~s}$; (b) $10 \mathrm{~s}$; ${ }^{\circ} \mathrm{C}$ ) $30 \mathrm{~s}$; (d) $60 \mathrm{~s}$; (e) $600 \mathrm{~s}$; (f) $3600 \mathrm{~s}$ (M: martensite; MA: martensite-austenite islands; BF: Bainitic ferrite; GB: granular bainite; AF: acicular ferrite; PF: polygonal ferrite; P: pearlitic)

LOM micrographs of the LePera specimens are shown in Fig. 5. In Fig. 5, ferrite appeared gray, pearlite and bainite appeared dark, and both martensite and MA islands appeared white after LePera etching. The gray-colored ferrite and white martensite/MA islands produced after thermal cycling could clearly be distinguished. LePera etching provides results that polygonal ferrite, pearlite and bainite appeared gray and black, respectively when the specimen was isothermally held for $3600 \mathrm{~s}$ (Fig. 5 (f)).
Three lines which possessed different angle were drawn in the photomicrograph, the length values of the line were produced automatically. Then took count of the number of the grain size, finally calculate th average of the ferrite grain size. The results of the ferrite grain size and the volume fractions of microstructure constituents are shown in Table 1. Grain was the finest for isothermal holding times of $5 \mathrm{~s}$, and average grain size had the lowest value $(5.89 \mu \mathrm{m})$. The maximum ferrite grain size $(10.55 \mu \mathrm{m})$ was obtained for isothermal holding time of $30 \mathrm{~s}$. 

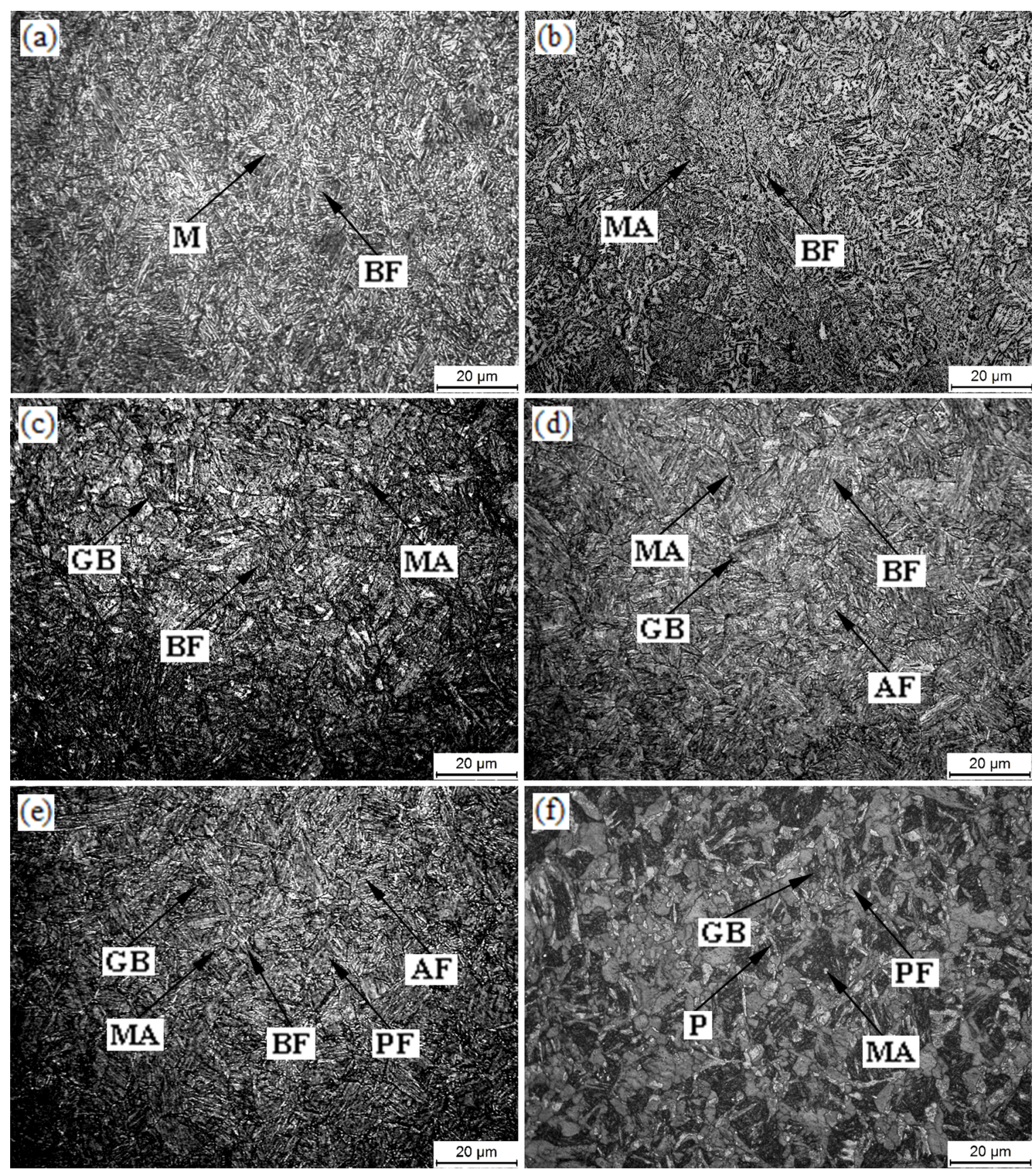

Figure 5. LOM micrographs of the specimens held for (a) $5 \mathrm{~s}$; (b) $10 \mathrm{~s} ;{ }^{\circ} \mathrm{C}$ ) $30 \mathrm{~s}$; (d) $60 \mathrm{~s}$; (e) $600 \mathrm{~s}$; (f) $3600 \mathrm{~s}$ (M: martensite; MA: martensite-austenite islands; BF: Bainitic ferrite; GB: granular bainite; AF: acicular ferrite; PF: polygonal ferrite; P: pearlitic)

Table 1. Volume fractions of microstructure constituents and the ferrite grain size

\begin{tabular}{lccccccc}
\hline Specimens & $\begin{array}{c}\text { Granular } \\
\text { bainite } / \%\end{array}$ & Pearlite $/ \%$ & $\begin{array}{c}\text { Bainitic ferrite } \\
/ \%\end{array}$ & $\begin{array}{c}\text { Acicular } \\
\text { ferrite } / \%\end{array}$ & $\begin{array}{c}\text { Polygonal } \\
\text { ferrite } / \%\end{array}$ & $\begin{array}{c}\text { Martensite } \\
\text { (martensite-austenite } \\
\text { islands) } / \%\end{array}$ & $\begin{array}{c}\text { Average grain } \\
\text { size } / \mu \mathrm{m}\end{array}$ \\
\hline $5 \mathrm{~s}$ & - & - & $76.8 \pm 3.2$ & - & - & $23.2 \pm 1.5$ & $5.89 \pm 0.5$ \\
$10 \mathrm{~s}$ & $9.7 \pm 3.4$ & - & $70.2 \pm 3.1$ & - & - & $20.3 \pm 1.6$ & $6.44 \pm 0.4$ \\
$30 \mathrm{~s}$ & $18.8 \pm 4.1$ & - & $66.8 \pm 4.3$ & & - & $14.4 \pm 0.5$ & $10.52 \pm 0.13$ \\
$60 \mathrm{~s}$ & $21.8 \pm 4.0$ & - & $64.8 \pm 0.9$ & & & $13.4 \pm 3.1$ & $9.06 \pm 0.52$ \\
$600 \mathrm{~s}$ & $24.2 \pm 3.1$ & - & $65.4 \pm 3.1$ & & & & \\
$3600 \mathrm{~s}$ & $42.7 \pm 4.6$ & & - & - & $53.1 \pm 5.9$ & $4.4 \pm 0.5$ & $8.21 \pm 0.50$ \\
\hline
\end{tabular}


The ferrite grain size first increased and then decreased with increasing holding time. The large volume fractions ( $23.2 \%$ and $20.3 \%$ ) of formed martensite in the specimens for the isothermal holding time of 5 and $10 \mathrm{~s}$ at $700^{\circ} \mathrm{C}$ were apparent (Fig. 5, Table 1). The martensite lessened with increasing holding time. Martensite/martensite-austenite islands exhibited higher levels for isothermal holding times of 30-600 s. The amount of martensite-austenite islands decreased when the specimen was isothermally held for $3600 \mathrm{~s}$.
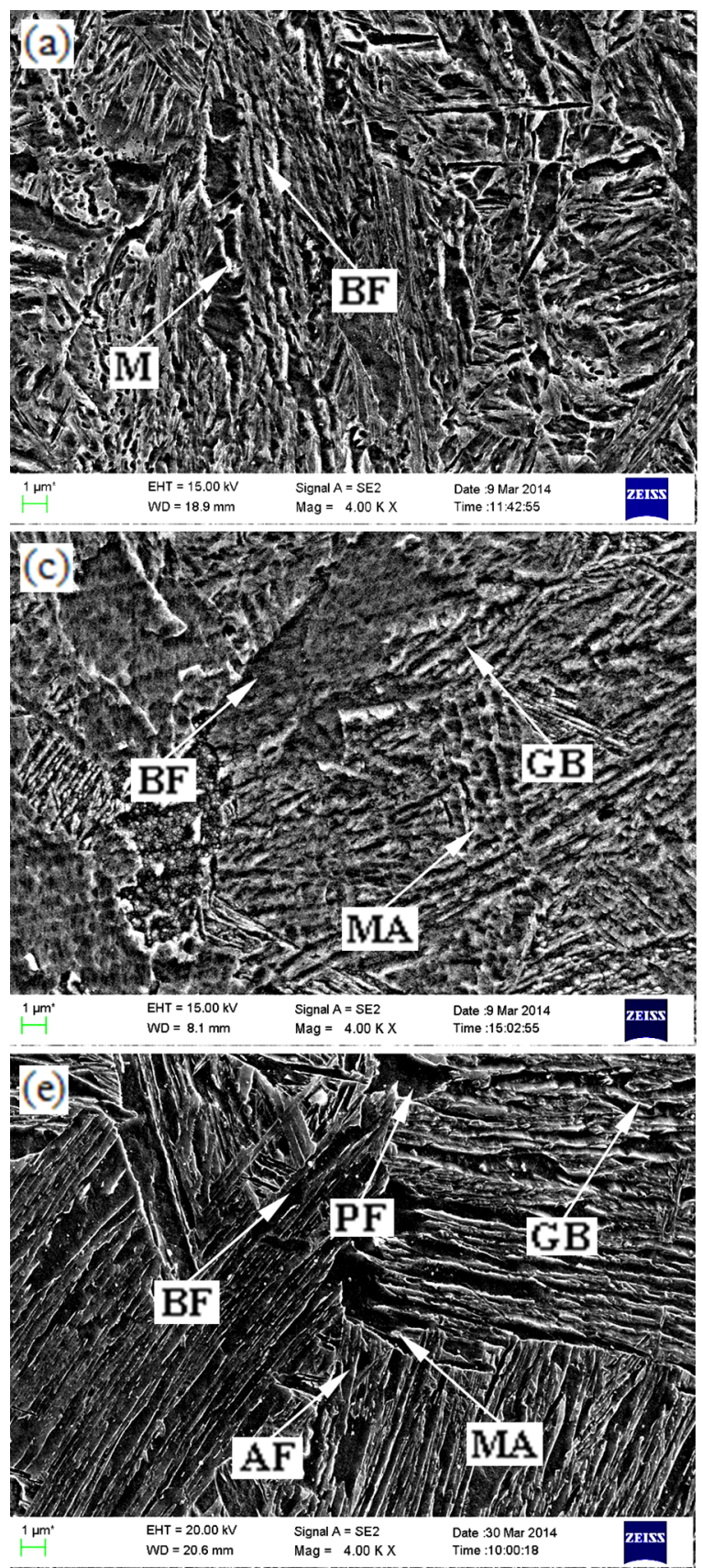

Figure 6. SEM micrographs of the specimens held for (a) $5 \mathrm{~s}$; (b) $10 \mathrm{~s}$; ${ }^{\circ} \mathrm{C}$ ) $30 \mathrm{~s}$; (d) $60 \mathrm{~s}$; (e) $600 \mathrm{~s}$; (f) $3600 \mathrm{~s}$ (M: martensite; MA: martensite-austenite islands; BF: Bainitic ferrite; GB: granular bainite; AF: acicular ferrite; PF: polygonal ferrite; P: pearlitic)

\subsection{Electron microscopy}

SEM micrographs of the experimental steel specimens are shown in Fig. 6. Martensite was found in the specimen after isothermal holding for 5 and $10 \mathrm{~s}$ (Figs. 6 (a, b)). Bainitic ferrite was the transformed plates shape when the specimens The GB containing martensite-austenite (MA) constituents formed with increasing holding time (Table 2, Figs. 6 (b-f)). were isothermally held for 5, 10, 30, and 60 s (Figs. 6 (a-d)).
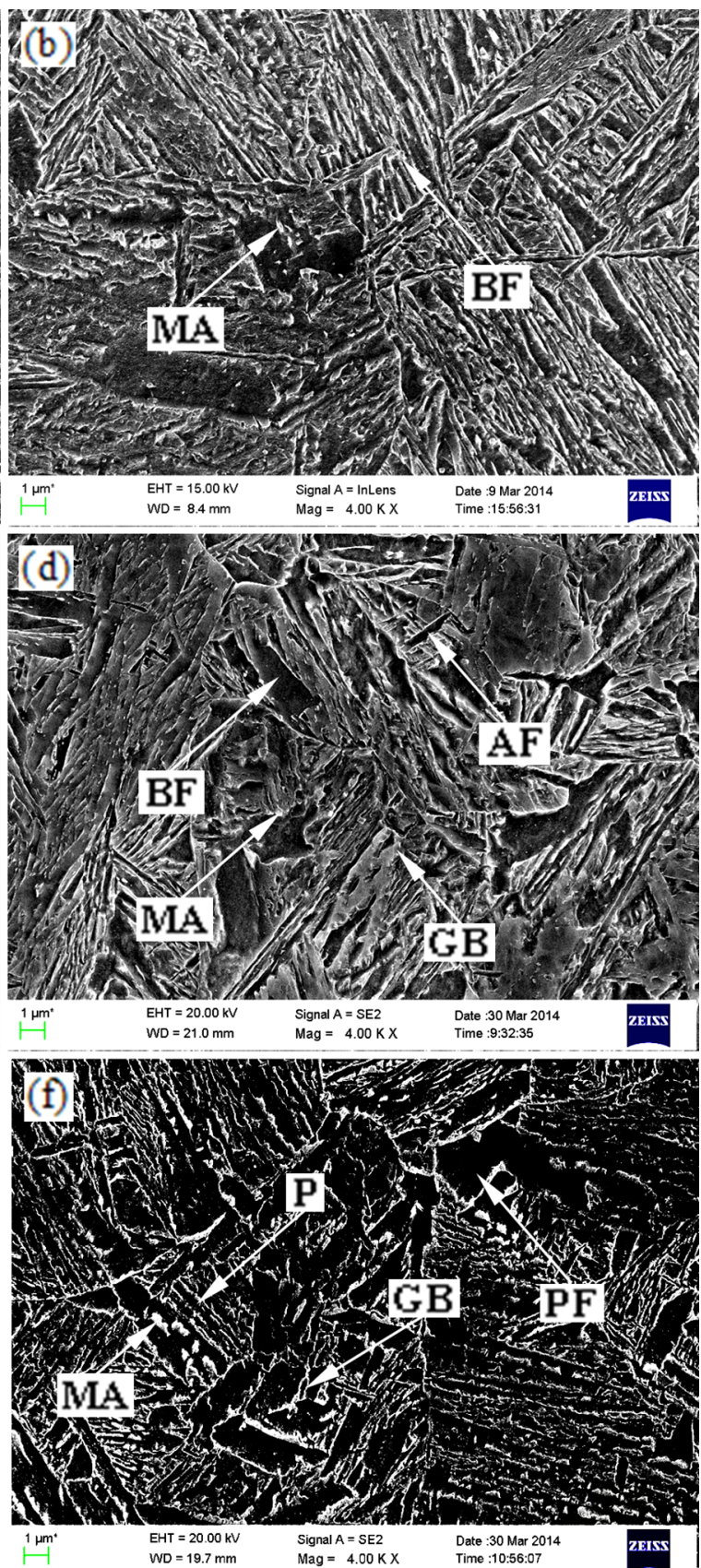
Table 2. Measured volume fraction and average size of precipitates

\begin{tabular}{lcc}
\hline Specimens & Volume fraction $/ \%$ & Average size $/ \mathrm{nm}$ \\
\hline $5 \mathrm{~s}$ & 1.585 & 5.9014 \\
$30 \mathrm{~s}$ & 1.643 & 6.2431 \\
$600 \mathrm{~s}$ & 1.911 & 6.8216 \\
$3600 \mathrm{~s}$ & 4.785 & 9.7609 \\
\hline
\end{tabular}

Acicular ferrite was observed when the specimens were isothermally held for 30, 60 and 600 s (Table 2, Figs. 6 (c-e)). Pearlite can be seen when the specimen was isothermally held for $3600 \mathrm{~s}$ (Table 2, Fig. 6 (f)).
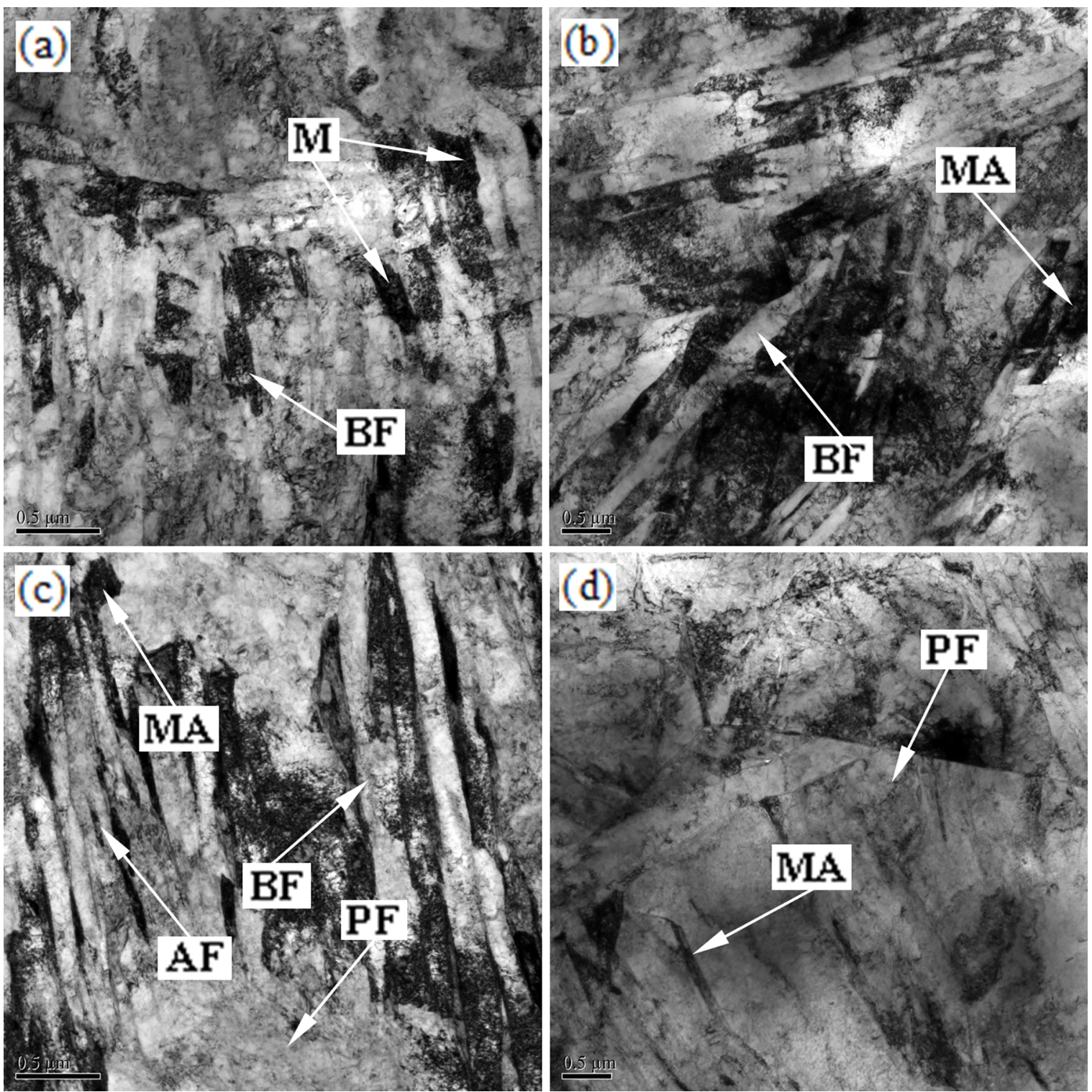

Figure 7. TEM micrographs of the specimen for (a) $5 \mathrm{~s}$; (b) $30 \mathrm{~s}$; ${ }^{\circ} \mathrm{C}$ ) $600 \mathrm{~s}$; (d) $3600 \mathrm{~s}$ (M: martensite; BF: bainitic ferrite; MA: martensiteaustenite islands; AF: acicular ferrite; PF: polygonal ferrite)
Fig. 7 shows TEM micrographs when the specimesn were isothermally held for 5, 30, 600 and $3600 \mathrm{~s}$. The microstructure consists of islands of martensite in a bainitic ferrite matrix (Fig. 7 (a)). Bainitic ferrite and martensite-austenite islands are observed in Fig. 7 (b). Granular bainite coexists with polygonal ferrite (Fig. 7 (c)). The characteristics of granular bainite and polygonal ferrite are found in Fig. 7 (d).

The interphase precipitation apparently occurred at the grain and subgrain boundaries. The precipitates could be observed when the specimens were isothermally held for 5, 30, 600 and $3600 \mathrm{~s}$. The quantity of the dispersed precipitates particles was little in the specimen after isothermal holding for $5 \mathrm{~s}$. 
It was difficult to observe the precipitates which existed either in the grain boundaries or within the lattice structure of the lath-like bainitic ferrite (Fig. 8 (a)). There appeared to be more precipitates when the specimen was isothermally held for $30 \mathrm{~s}$ (Fig. 8 (b)).
Large dimension of precipitate particle was found for isothermal holding times of $600 \mathrm{~s}$ (Fig. 9 (a)). Its morphology was close to round-shaped, and its diameter reached approximately $91.43 \mathrm{~nm}$. The EDS analysis of the particle indicated that it was an undissolved $\mathrm{Nb}$ carbonitride precipitate (Fig. 9 (b)).
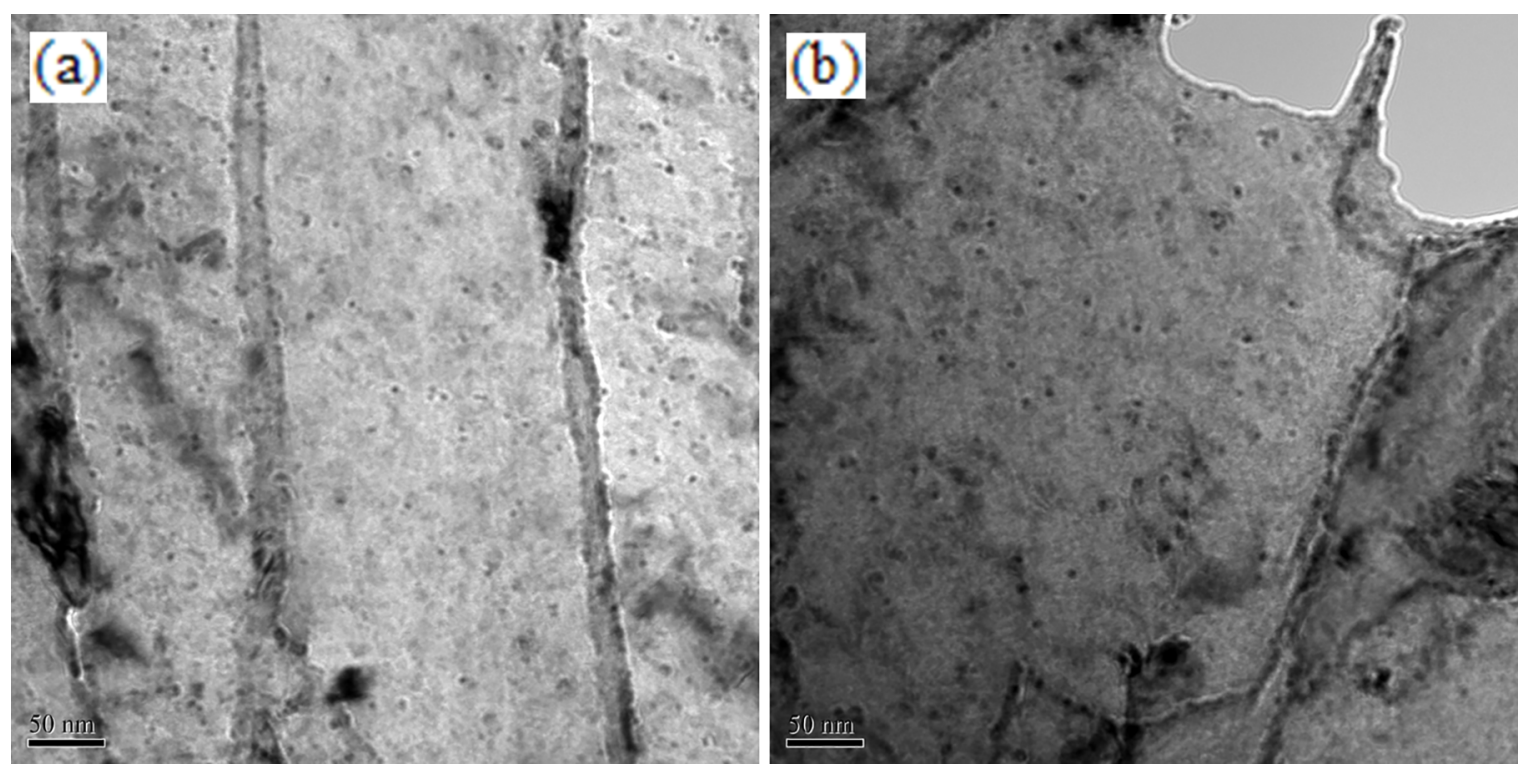

Figure 8. TEM micrograph of the specimen for (a) $5 \mathrm{~s}$; (b) $30 \mathrm{~s}$
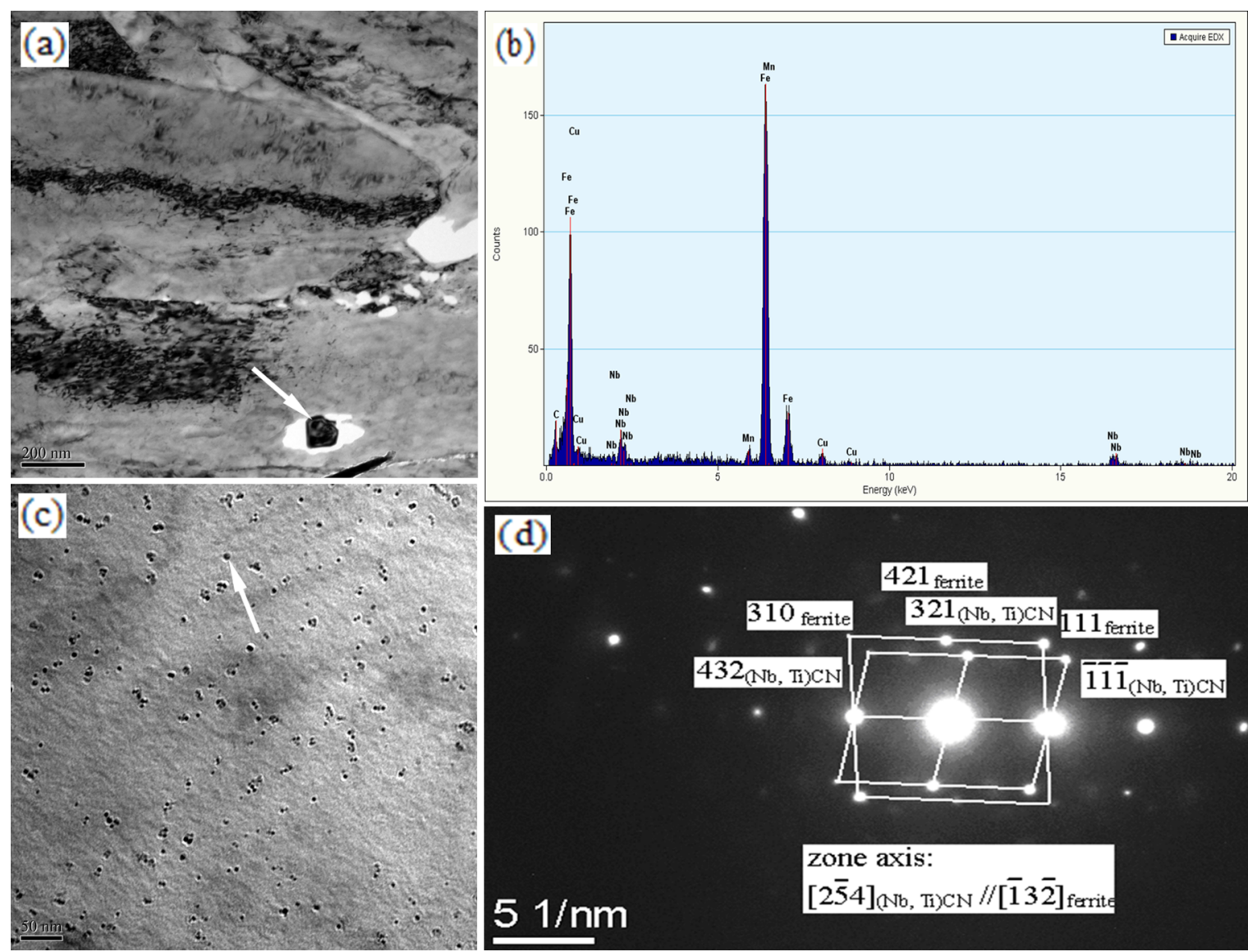

Figure 9. TEM micrograph of the specimen for $600 \mathrm{~s}$ (a) (b) the precipitate particle and its EDS image; ${ }^{\circ} \mathrm{C}$ ) the precipitate; (d) its SADP 
It should belong to an undissolved $\mathrm{Nb} / \mathrm{Ti}$ carbonitride precipitate. A lot of fine dispersed precipitates within the bainitic ferrite are observed (Fig. 9 (c)). An fcc (Ti, Nb) $(\mathrm{N}, \mathrm{C})$ particle was verified by a selected area diffraction pattern (SADP) measurements (Fig. 9 (d)). They were the MX-type precipitates.

Relatively coarse dispersed precipitates distinctly increased when the specimen was isothermally held for $3600 \mathrm{~s}$ (Fig. 10 (a)). An SADP derived from a particle shown in Fig. 10 (b) indicates that it was also an fcc (Ti, Nb) (N, C) particle. They were also the MX-type precipitates.

The results of volume fraction and average size of the precipitates are given in Table 2.

\subsection{Vickers hardness}

Average hardness data for each specimen after different isothermal holding times at $700^{\circ} \mathrm{C}$ was obtained. Mean square deviation of the hardness value was Hv19.94. Comparison of Vickers hardness distribution is shown in Fig. 11. Vickers hardness first gradually increased with prolonged holding time from 5 to $10 \mathrm{~s}$. This was because the strengthening effect was attributed to the not only martensite, but precipitation, despite there was little dispersed precipitate particle when the specimen was isothermally held for $5 \mathrm{~s}$ (Fig. 8). Then, the hardness increased rapidly due to the precipitation strengthening of finely dispersed precipitate particles when the specimen was isothermally held for $30 \mathrm{~s}$ at $700^{\circ} \mathrm{C}$. It is essential that the hardness increased from 30 to 600 s all the time. The maximum hardness value of Hv312 was obvious because of the notable precipitation strengthening for $600 \mathrm{~s}$. Finally, the hardness decreased with increasing holding time. This was attributed to a lot of polygonal ferrite and a decrease of the precipitation strengthening effect because average size of precipitates increased (Table 2).
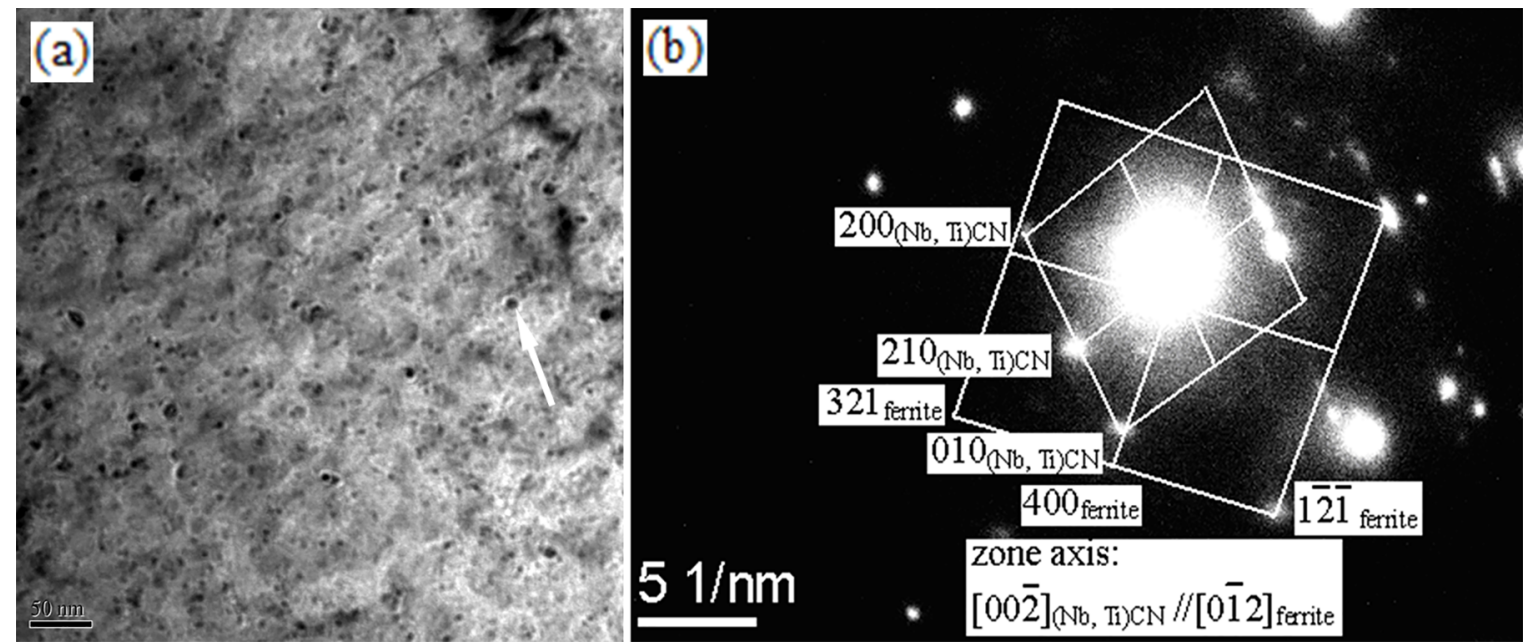

Figure 10. TEM micrograph of the specimen for $3600 \mathrm{~s}$ (a) the precipitates; (b) its SADP

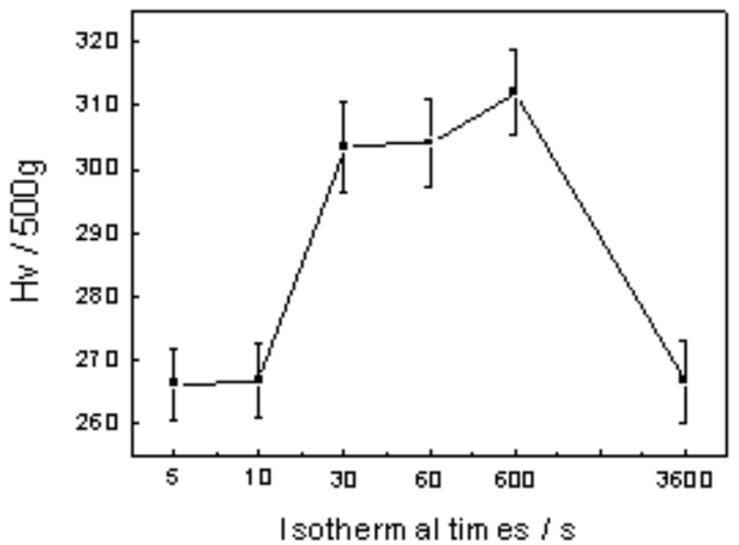

Figure 11. The variation of Vickers hardness with holding times

\subsection{Microstructural evolution and the precipitation behavior}

\subsubsection{Microstructural evolution}

Microstructure constituents should be important factors in enhancing the mechanical properties of steel. As mentioned above, $700^{\circ} \mathrm{C}$ is above $\mathrm{Ac}_{1}$, there was small quantity of martensites due to water-quenching for isothermal holding times of 5 and $10 \mathrm{~s}$ at $700^{\circ} \mathrm{C}$ (Fig. 2, Table 1). However, the variational results of Vickers hardness of the specimens showed that the effect of martensite strengthening was faint (Fig. 11). The dominant microstructural constituent of the steel was certainly bainitic ferrite. 
The precipitation of alloy carbides was the predominant strengthening effect at this thermal cycling condition. The interphase precipitation did not have time to occur for too short isothermal holding times, despite there was only a small amount of precipitate present for isothermal holding time of $5 \mathrm{~s}$ at $700^{\circ} \mathrm{C}$ (Fig. 10), and these precipitates were not the interphase precipitation. The strengthening contributions of precipitates were the lowest values (Table 2). This explained why the hardnesses exhibited low values when the specimens were isothermally held for 5 and $10 \mathrm{~s}$, even though martensite formed $(23.2 \%$ and $20.3 \%$, respectively) and ferrite grains refined.

The microstructures consisted mainly of bainitic ferrite in the steel for isothermal holding times of 30$600 \mathrm{~s}$. The lath-like bainitic ferrite containing high density of dislocations contributed to the enhancement of the hardness. The strengthening effect of granular bainite was presented at long isothermal holding time. A certain amount of acicular ferrite gradually arose for isothermal holding times of 30-600 s. By increasing the amount of acicular ferrite (AF) in the microstructure, steel toughness could be improved significantly ${ }^{18}$. Therefore, increase of the strength did not result in a decrease of total elongation largely for isothermal holding times of 30-600 s.

\subsubsection{The strengthening contribution of precipitates}

Dynamic recrystallization is known to be the major restoration process during hot deformation of low carbon microalloyed steels ${ }^{19}$. However, strong carbide formers, such as $\mathrm{V}, \mathrm{Ti}$ and $\mathrm{Nb}$ would inhibit recrystallisation of the steel. The addition of microalloying elements in solid solution delayed the occurrence of dynamic transformation. The forward nucleation of ferrite occurred displacively while the retransformation back into austenite took place by a diffusional mechanism ${ }^{20}$. As mentioned above, austenitic solution temperature was put at $1250^{\circ} \mathrm{C}$, this is because microalloying elements make the solution treatment response sluggish and therefore necessitate higher temperature to produce the solution results. Some carbonitrides were dissolved as much as possible during this temperature. Strong carbide-forming alloying elements promoted the formation of carbides and carbonitrides. The carbide/ carbonitride particles precipitated nucleation and growth during TMCP and isothermal stage. The strain-induced precipitation occurred mainly at dislocations and subgrain boundaries introduced by hot deformation ${ }^{21}$. It provided effective precipitation strengthening for the present steel. The precipitation behavior could decide the changes of the hardness curves.
According to Shahrooz ${ }^{22}$, as such the strengthening contribution is calculated using the Ashby-Orowan model which adequately describes the strengthening of precipitates between 3-30 $\mathrm{nm}$ sizes:

$$
\sigma=\alpha \frac{G b}{2 \pi L} \ln \beta \frac{r}{b}
$$

Where, $\alpha$ and $\beta$ are constants, i.e 2.4 and 0.8 respectively, $G$ denotes the shear modulus; $80.3 \mathrm{GPa}, b$ is the magnitude of the Burger's vector, $2.5 \times 10^{-10} \mathrm{~m}, r$ is particle radius and $L$ represents interparticle spacing given by $L=r \sqrt{2 \pi / 3 f}$ ( $\mathrm{f}$ is volume fraction). The results of calculated strengthening contribution of the precipitates are given in Table 3.

Table 3. The strengthening contribution of precipitates

\begin{tabular}{lc}
\hline Specimens & Strength / MPa \\
\hline $5 \mathrm{~s}$ & 43.315 \\
$30 \mathrm{~s}$ & 47.416 \\
$600 \mathrm{~s}$ & 63.048 \\
$3600 \mathrm{~s}$ & 53.294 \\
\hline
\end{tabular}

In Table 3, the strengthening contributions of precipitates reached $43.315 \mathrm{MPa}, 47.416 \mathrm{MPa}, 63.048 \mathrm{MPa}$ and 53.294 MPa when the specimens were isothermally held for 5, 600 and $3600 \mathrm{~s}$, respectively. This meant that Vickers hardness was mainly attributed to the precipitation strengthening. The hardness variation was decided by precipitation strengthening and the contribution of the matrix (mainly bainitic ferrite).

\subsubsection{The interphase precipitation and the hardness}

The smallest ferrite grain size $(5.89 \mu \mathrm{m})$ was obtained due to water cooling after held $5 \mathrm{~s}$ at $700^{\circ} \mathrm{C}$. At the same time, the ferrite grain size was the maximum value $(10.52$ $\mu \mathrm{m}$ ) for isothermal holding time of $30 \mathrm{~s}$. It is considered a relatively minor contribution from fine ferrite grain in the present study occurred. And higher hardness value (Hv303) was obtained for isothermal holding time of $30 \mathrm{~s}$. This was because the martensite and boundary strengthening effect became weak. It was well known that the interphase precipitation could occur in ferrite at the austenite/ferrite interface ${ }^{23}$. Precipitates could suppress grain growth because of pinning effect. The volume fraction and average size of the precipitates mentioned in Table 2 reached the maximum value after held $3600 \mathrm{~s}$. The precipitates provide effective grain refinement although the coarsening of the particles results in a considerable decrease in the precipitation strengthening. The precipitates do retard grain growth to some extent. As a result, the coarsening of the ferrite grain size was controlled for isothermal holding times of 60, 600 and $3600 \mathrm{~s}$ (Table 1). 
The variation of Vickers hardness for the experiments described in Fig. 11 had also been related to the ferrite grain size. On the other hand, it was proposed that the precipitation strengthening played a more important role than grain refinement in enhancing the mechanical properties of linepipe steel. From a commercial perspective, the formation of interphase precipitation during TMCP was interesting for the linepipe steel production. Vickers hardnesses of the specimen exhibited high values for isothermal transformation of 30 to $600 \mathrm{~s}$ at $700^{\circ} \mathrm{C}$ (Fig. 11). This was because the interphase precipitation was a major microstructural contributor to the hardness (strength) ${ }^{11}$. The interphase precipitation resulted in a strengthening of the matrix ${ }^{24}$. The strengthening effect was apparent for this condition. The hardness increased rapidly at $30 \mathrm{~s}$ (Fig. 11). Therefore, the interphase precipitation seemed to begin for isothermal holding time greater than $30 \mathrm{~s}$.

The interphase precipitation increased in frequency with prolonged holding at $700^{\circ} \mathrm{C}$. The hardness of $\mathrm{X} 90$ linepipe steel showed sharp increases to the peak owing to the precipitation of very finely dispersed carbide/carbonitride at $600 \mathrm{~s}$. The nanoprecipitates were formed through transition of solute clusters and/ or metastable precipitates that had a composition and structure different from the stoichiometric equilibriumphase ${ }^{25}$. These precipitate particles, except the formation of the undissolved precipitates, included the precipitation of $\mathrm{Nb} / \mathrm{Ti}$ carbonitride precipitate during the deformation and the subsequent cooling and isothermal stage after deformation. They were fcc (Ti, Nb) (N, C) particles which belonged to the MX-type precipitates (Fig. 9). The main precipitates intervening in increasing strength was carbonitrides even though the nitrogen content was low (45ppm). Consequently, the strengthening contribution of precipitates reached the maximum value under this condition (Table 3). Vickers hardness reached the maximum value for the specimen after isothermal holding for $600 \mathrm{~s}$. This was because effective precipitation strengthening was provided in this case. It was favorable for the applications in the linepipe steel production process.

It was clear that large amounts of polygonal ferrite even pearlite gradually emerged with prolonged holding at $700^{\circ} \mathrm{C}$. The hardness value dropping was attributed to the variational results of microstructure constituents (Fig. 11 and Table 1). The presence of large amounts of polygonal ferrite resulted in the decrease of the hardness value. On the other hand, the precipitates could distribute throughout the specimens with long time retention. They also belonged to the MX-type precipitates (Fig.10 (b)). Average size of precipitates reached the maximum value, and the strengthening contribution of precipitates markedly decreased over a long time period during isothermal holding (Table 3 ). The beneficial effects of precipitation strengthening decreased due to the coarsening of the precipitates (Fig.10 (a, b)). It affected the hardnesses. As a result, the variation of Vickers hardness took on a phenomenon of rise and decrease.

\section{Conclusions}

1. Bainitic ferrite, acicular ferrite and granular bainite transformation occurred with increasing holding times at $700^{\circ} \mathrm{C}$. There was the amount of martensite in the microstructure for isothermal holding times of 5 and $10 \mathrm{~s}$ at $700^{\circ} \mathrm{C}$. The effects of martensite strengthening were weak. The hardness value dropping was attributed to formed polygonal ferrite for the specimens after isothermal holding for $3600 \mathrm{~s}$ at $700^{\circ} \mathrm{C}$.

2. The precipitation strengthening played a more important role during holding isothermal for X90 linepipe steel. The changes of the hardness curves were decided by the precipitation behavior. The interphase precipitation seemed to begin for isothermal holding time greater than $30 \mathrm{~s}$. It had a peak value for isothermal holding time of $600 \mathrm{~s}$. Some fcc $(\mathrm{Ti}, \mathrm{Nb})(\mathrm{N}, \mathrm{C})$ particles which belonged to the MX-type precipitates were obtained at this condition. Vickers hardness was mainly attributed to the precipitation strengthening.

3. The beneficial effects of precipitation strengthening decreased due to the coarsening of the precipitates with prolonged holding, which resulted in the hardness quickly dropping. As a result, the hardness exhibited a low value after isothermal holding for $3600 \mathrm{~s}$ because the extent of precipitation strengthening was lessened and a lot of polygonal ferrites were formed.

\section{Acknowledgments}

This work was supported by the National 863 project of China (2015AA03A501) and Liaoning Provincial Science and Technology Plan Project (2015020189).

\section{References}

1. van Landeghem HP, Catteau SD, Teixeira J, Dulcy J, Dehmas M, Courteaux M, et al. Isothermal Decomposition of carbon and nitrogen-enriched austenite in 23MnCrMo5 low-alloy steel. Acta Materialia. 2018;148(15):363-373.

2. Liu S, Challa VSA, Natarajan VV, Misrta RDK, Sidorenko DM, Mulholland MD, et al. Significant influence of carbon and niobium on the precipitation behavior and microstructural evolution and their consequent impact on mechanical properties in microalloyed steels. Materials Science and Engineering: $A$. 2017;683:70-82

3. Sasidhar KN, Dhande T, Javed N, Ghosh A, Mukherjee M, Sharma V, et al. Effect of transformation texture on the impact toughness of hot-rolled $\mathrm{Ti}+\mathrm{Nb}$ microalloyed steel. Materials \& Design. 2017;128:86-97. 
4. Anant R, Ghosh PK. Ultra-narrow gap welding of thick section of austenitic stainless steel to HSLA steel. Journal of Materials Processing Technology. 2017;239:210-221.

5. Mohebbi MS, Parsa MH, Rezayat M, Orovcík L. Analysis of Flow Behavior of an Nb-Ti Microalloyed Steel During Hot Deformation. Metallurgical and Materials Transactions A. 2018;49(5):1604-1614

6. Wang JT, Hodgson PD, Bikmukhametov I, Miller MK, Timokhina I. Effects of hot-deformation on grain boundary precipitation and segregation in Ti-Mo microalloyed steels. Materials \& Design. 2018;141:48-56.

7. Jung JG, Park JS, Kim J, Lee YK. Carbide precipitation kinetics in austenite of a Nb-Ti-V microalloyed steel. Materials Science and Engineering: A. 2011;528(16-17):5529-5535.

8. Gunabalapandian K, Samanta S, Ranjan R, Singh SB. Investigation of Austenitization in Low Carbon Microalloyed Steel During Continuous Heating. Metallurgical and Materials Transactions A. 2017;48(5):2099-2104.

9. Jung JG, Shin E, Lee YK. Separate Evaluation of the Kinetics of Carbide Precipitation Occurring at the Interface of Preexisting Particles and Within the Austenitic Matrix in a Microalloyed Steel. Metallurgical and Materials Transactions A . 2017;48(1):76-85.

10. Zhang YJ, Miyamoto G, Shinbo K, Furuhara T. Effects of a/? orientation relationship on VC interphase precipitation in lowcarbon steels. Scripta Materialia. 2013;69(1):17-20.

11. Dunne DP. Review: interaction of precipitation with recrystallisation and phase transformation in low alloy steels. Materials Science and Technology. 2010;26(4):410-420.

12. Llanos L, Pereda B, Lopez B, Rodriguez-Ibabe JM. Hot Deformation and static softening behavior of vanadium microalloyed high manganese austenitic steels. Materials Science and Engineering: A. 2016;651:358-369.

13. Astafurova E, Maier G, Melnikov E, Naydenkin E, Smirnov A, Bataev V, et al. The Influence of the Thermomechanical Processing Regime on the Structural Evolution of Mo-Nb-Ti-V Microalloyed Steel Subjected to High-Pressure Torsion. Metallurgical and Materials Transactions A. 2017;48(7):3400-3409.

14. Schaupp T, Schroepfer D, Kromm A, Kannengieser T. Welding residual stresses in $960 \mathrm{MPa}$ grade QT and TMCP high-strength steels. Journal of Manufacturing Processes. 2017;27:226-232.
15. Isasti $\mathrm{N}$, Jorge-Badiola $\mathrm{D}$, Taheri ML, Uranga P. Microstructural Features Controlling Mechanical Properties in Nb-Mo Microalloyed Steels. Part II: Impact Toughness. Metallurgical and Materials Transactions A. 2014;45(11):4972-4982.

16. Tian Y, Wang HT, Wang ZD, Misra RDK, Wang GD. Microstructural Evolution and the Precipitation Behavior in X90 Linepipe Steel During Isothermal Processing. Journal of Materials Engineering and Performance. 2018;27(4):14941504.

17. Girault E, Jacques P, Harlet P, Mols K, van Humbeeck J, Aernouldt E, et al. Metallographic Methods for Revealing the Multiphase Microstructure of TRIP-Assisted Steels. Materials Characterization. 1998;40(2):111-118.

18. Loder D, Michelic SK. Systematic investigation of acicular ferrite formation on laboratory scale. Materials Science and Technology. 2017;33(2):162-171.

19. Momeni A, Arabi H, Rezaei A, Badri H, Abbasi SM. Hot deformation behavior of austenite in HSLA-100 microalloyed steel. Materials Science and Engineering: A. 2011;528(45):2158-2163.

20. Aranas C Jr., Wang T, Jonas JJ. Effect of Interpass Time on the Dynamic Transformation of a Plain C-Mn and a Nb Microalloyed Steel. ISIJ International. 2015;55(3):647-654.

21. Park JS, Ha YS, Lee SJ, Lee YK. Dissolution and Precipitation Kinetics of $\mathrm{Nb}^{\circ} \mathrm{C}, \mathrm{N}$ ) in Austenite of a Low-Carbon $\mathrm{Nb}$ Microalloyed Steel. Metallurgical and Materials Transactions A. 2009;40(3):560-568.

22. Nafisi S, Amirkhiz BS, Fazeli F, Arafin A, Glodowski R, Collins L. Effect of Vanadium Addition on the Strength of API X100 Linepipe Steel. ISIJ International. 2016;56(1):154-160.

23. Yen HW, Chen PY, Huang CY, Yang JR. Interphase precipitation of nanometer-sized carbides in a titanium-molybdenum-bearing low-carbon steel. Acta Materialia. 2011;59(16):6264-6274.

24. Clark S, Janik V, Lan Y, Sridhar S. Interphase Precipitation - An Interfacial Segregation Model. ISIJ International. 2017;57(3):524532 .

25. Timokhina I, Miller MK, Wang JT, Beladi H, Cizek P, Hodgson $\mathrm{PD}$. On the Ti-Mo-Fe-C atomic clustering during interphase precipitation in the Ti-Mo steel studied by advanced microscopic techniques. Materials \& Design. 2016;111:222-229. 